\title{
Analysis of Wound Healing from Andaliman Fruit Essential Oil Ointment (Zanthoxylum Canthopodium Dc.) on Wistar Rats (Rattus Norvegicus)
}

\author{
$\underline{\text { Xu Xuliang }}{ }^{1}$, Florenly ${ }^{2}$, Johannes Bastira Ginting ${ }^{3}$, Fioni ${ }^{4}$ \\ 1,2,3,4 Master of Clinical Medicine, Faculty of Medicine, Universitas Prima Indonesia \\ Email: johannesbastiraginting@unprimdn.ac.id
}

\begin{abstract}
:
Injuries are cases of injury that are often experienced by every human being. A wound is the loss or damage of some body tissue. Many andaliman fruits contain many phytochemicals such as phenols, saponins, flavonoids, triterpioids, and alkaloids. Its terpenoid content has antioxidant and antimicrobial activity repellents. Iris / incision wounds, which are wounds caused by sharp object slices such as knives, cause damage to vessels that are large enough if the slice is deep enough. This study aims to find out the effect of Andaliman Fruit Essential Oil Saleb (Zanthoxylum acanthopodium DC.) on wound healing in white rats. This experimental study with the approach of Pre-test and Post-test group only control design was conducted January to February 2021, at the Herbarium Medanese FMIPA USU, the Pharmacognosive Laboratory of the Faculty of Pharmacy USU, and the Laboratory of Pharmaceutical Pharmacology USU. The samples were Andaliman Fruit (Zanthoxylum acanthopodium DC.), and male white rats. The number of samples using frederer formula, so determined the number of as many as 25 rats selected randomly divided into 5 groups. Data analysis uses the normality test statistical data test, and the ANOVA test. The results of the study that andaliman fruit extract has several bioactive compounds such as alkaloids, flavonoids, saponins, and tannins that play a role in wound healing. The optimum concentration of Saleb Andaliman fruit essential oil that can heal wounds in white rats is 5\%. The highest percentage of cures on the 14 th day was in positive control (Bioplacenton $\AA$ ) which was $95 \%$ and followed by an extract of $5 \% \mathrm{v} / \mathrm{v}$ with a cure percentage of $90 \%$. Essential oil of andaliman fruit extract has the ability to approach Bioplacenton ${ }^{\circledR}$ in healing wounds in mice.
\end{abstract}

Keywords:

ointment; andaliman; sores

\section{Introduction}

Injuries are cases of injury that are often experienced by every human being. Wounds are the loss or damage of some body tissues (Suarni and Prameswarie, 2015), because of a factor that interferes with the body's protective system (Afandi, 2017). Data Riset Kesehatan Dasar, 2013 stated the number of causes of unintentional injuries such as falls from motorcycles, sharp objects / blunts, land transportation and falls with a prevalence rate of 0.7 percent of the total population of Indonesia (RISKESDAS, 2013). The wound healing phase is various in several phases, namely the inflammatory phase, proliferative phase and maturase phase (Novyana and Susanti, 2016). The inflammatory phase is characterized by hemostasis, chemotaxis (Wissen et al., 2020). The proliferative phase is characterized by the formation of granulation tissues, reepitelization, and neovascularization. The maturation and remodeling phase is where the wound reaches maximum strength (Kartika et al., 2015); (Hernawati, 2015); (Hardhani, Lastianny and Herawati, 2014). 
Since ancient times, plants have been used in medicine and are still used today. It is estimated that there are about 350,000 plants (trachaeophyta) that have potensoi into medicinal plants, but about $10 \%$ of them are about half a million species used as medicinal plants (Salmerón-Manzano, Garrido-Cardenas and Manzano-Agugliaro, 2020). Many andaliman fruits contain many phytochemicals such as phenols, saponins, flavonoids, triterpineoids, and alkaloids (Saragih and Arsita, 2019); (Batubara, 2017; Situmorang et al., 2019; Hong, et al., 2019).

Some studies prove that its terpenoid content has antioxidant activity repellents (Sitanggang et al., 2019), Antimicrobial (Yanti et al., 2011; Worotikan, Tuju and Kawuwung, 2017; Winarti, Simanjuntak and Syahidin, 2018; Sitanggang, Duniaji and Pratiwi, 2019a), and kill insects (Mery Sukmawati, Sumarto, 2013). Antioxidant activity and immunostimulating of the mainstay fruit that can increase the number of lymphocyte cells (Winarti et al., 2018). This study aims to find out the effect of Andaliman Fruit Essential Oil Saleb (Zanthoxylum acanthopodium DC.) on wound healing in white rats.

\section{Review of Literature}

Andaliman is included in the species Zanthoxylum acanthopodium DC (Sriwichai et al., 2019), it has a distinctive aroma and causes a tingling sensation on the tongue (Wijaya et al., 2019). Previous research has reported that andaliman seeds contain alkaloids and unsaturated fatty acids as well as terpenoids that have antioxidant effects (Rosidah et al., 2018a). Ethyl acetate extract from Andaliman fruit has high antioxidant activity with ic50 value of $66.91 \mathrm{BPJ}$, antioxidant activity in ethyl acetate extract is due to the presence of compound 2-methoxy-4-vinylol (Winarti, Simanjuntak and Syahidin, 2018). As an anti-bacterial, andaliman fruit has been shown to inhibit the growth of pathogenic bacteria significantly (Adolf J. N. Parhusip, 2006; Asbur, Y., 2018; Muzafri, 2019; Sitanggang, Duniaji and Pratiwi, 2019a). Other biological activities of the genus Zanthoxylum are as analgetic, antinosiseptic, antibiotic, anti-inflammatory, hepatoprotector, antiplastic, antiproliferative, antihelmintic, antiviral, antifungal and immunostimulative (Purba and Sinaga, 2017).

Iris / incision wounds, which are wounds caused by sharp object slices such as knives, cause damage to vessels that are large enough if the slice is deep enough. If the condition of the wound is aseptis then the wound will be immediately closed after the previous closure of blood vessels by leaving sutura-shaped marks. Wound healing mechanisms will naturally undergo several phases, namely the inflammatory phase (Morison 2004, proliferation phase (Sabirin et al 2013; Ningsih et al 2015), and the maturation or remodeling phase (Handayani et al. 2015).

\section{Research Methods}

This study is an experimental study with a Pre-test and Post-test group only control design approach that uses male wistar rats as test animals. This study was conducted January to February 2021, the entire study was conducted at the Herbarium Medanese FMIPA USU, the Pharmacognosy Laboratory of the Faculty of Pharmacy USU, and the Laboratory of Pharmaceutical Pharmacology USU. The samples used were Andaliman Fruit (Zanthoxylum acanthopodium DC.), and male white rats. Determination of the number of samples using frederer formula, so determined the number of as many as 25 randomly selected male white rats divided into 5 groups. 


\subsection{Material}

The materials used are alcohol, aluminum foil, aquadest, Andaliman fruit (Zanthoxylum acanthopodium DC.), ethanol 96\%, rat test animals (mus musculus), sterile gauze, whatman filter paper, methyl parabens, petroleum ether, plaster, propylene glycol, gloves, and triethanolamine.

\subsection{Tool}

Tools used include glass tools (pyrex®), autoclaves, maceration vessels, blenders (Maspion ${ }^{\circledR}$ ), porcelain cups, funnel lengths (Tricle brand $\left.{ }^{\circledR}\right)$, ovens, tweezers, rotavapor (Heidolf $\left.{ }^{\circledR}\right)$, iron spoons, analytical scales (Precisa $\left.{ }^{\circledR}\right)$, and water baths.

\subsection{Working Procedure}

a. Sample Processing.

The dry material of andaliman fruit (Zanthoxylum acanthopodium DC.) is smoothed into powder and forms simplisia (Kosasih et al., 2019).

b. Manufacture of Essential Oils of your fruit.

Andaliman fruit as much as (200 grams) is methylated by hydro-distillation process for 4 hours at a temperature of $80 \mathrm{oC}$, the remaining water residue in the distillation is removed by inserting anhydrous sodium sulfate, which is then filtered to obtain the oil.

c. Yield Calculation

$$
\text { Yield }(\%)=\frac{\text { Essential Oils of andaliman fruit } \mathrm{x} 100 \%}{\text { Number of samples of your fruit }}
$$

d. Phytochemical test (Identification of compound groups), phytochemical screening (Widowati et al., 2016, 2017, 2018).

e. Manufacture of Preparations of Andaliman Fruit Essential Oil Ointment.

Table 1. Topical Preparation of Each Ointment

\begin{tabular}{|c|c|c|c|c|}
\hline \multirow{2}{*}{ Material Name } & \multicolumn{4}{|c|}{ Formula/ concentration $(\%, v / v)$} \\
\hline & I & II & III & IV \\
\hline Andaliman fruit oil & 1 & 3 & 5 & 7 \\
\hline Lanolin & $2.5 \mathrm{~g}$ & $2.5 \mathrm{~g}$ & $2.5 \mathrm{~g}$ & $2.5 \mathrm{~g}$ \\
\hline Solid paraffin & $2.5 \mathrm{~g}$ & $2.5 \mathrm{~g}$ & $2.5 \mathrm{~g}$ & $2.5 \mathrm{~g}$ \\
\hline Cetostearyl alcochol & $2.5 \mathrm{~g}$ & $2.5 \mathrm{~g}$ & $2.5 \mathrm{~g}$ & $2.5 \mathrm{~g}$ \\
\hline White vaseline & $42.5 \mathrm{~g}$ & $42.5 \mathrm{~g}$ & $42.5 \mathrm{~g}$ & $42.5 \mathrm{~g}$ \\
\hline
\end{tabular}

f. Test Animal Preparation.

25 rats. Rats are divided into 5 groups, each group consists of 5 tails. 1 positive group, 4 treatment groups. Inclusion criteria include: white mice, male sex, age $6-8$ weeks, weight $150-200 \mathrm{~g}$, and healthy as long as the mice are given a cut on the back area along $2 \mathrm{~cm}$. Exclusion criteria include: mice sick during the adaptation period, sick during treatment, die during treatment.

g. Methods of Treatment in Rats.

Group I was given standard feed and given a saleb preparation of andaliman fruit (Zanthoxylum acanthopodium DC.) 1\% as much as $1 \mathrm{~g}$ applied once every 24 hours. Group II was fed standard and given a saleb preparation of andaliman fruit (Zanthoxylum acanthopodium DC.) 3\% as much as 1 gr was applied once every 24 hours. Group III was given standard feed and given a saleb preparation of andaliman fruit (Zanthoxylum acanthopodium DC.) 5\% as much as $1 \mathrm{~g}$ applied once every 24 hours. 
Group IV was fed standard and given a saleb preparation of andaliman fruit (Zanthoxylum acanthopodium DC.) $7 \%$ as much as $1 \mathrm{~g}$ applied once every 24 hours. Group V positive control, fed standard and applied $1 \mathrm{~g}$ Bioplacenton ${ }^{\circledR}$ once every 24 hours. Bioplacenton ${ }^{\circledR}$ in the form of placenta extract and neomycin sulfate, is very effective in wound care. Extra placenta is a biogenic stimulator that plays a role in accelerating cell regeneration and wound healing while neomycin sulfate as an antibiotic that kills various microbes. Observed changes that occur in the wound.

h. Giving Wounds.

A total of 25 rats that have been prepared, dianastesi using ether liquid, then shaved the rat's fur sufficiently on the back area. Each mouse was given an incision on their back that had been shaved. How to give incisions to rats, first install the base of the lower body of the rat then wash hands, use gloves, then disinfect the skin area to be given the incision using a sterile scalpel, do an incision along $2 \mathrm{~cm}$ with a depth of $1 \mathrm{~mm}$ from the surface of the skin of the white rat's back.

i. Antioxidant Test.

Antioxidant tests are conducted to see the antioxidant activity of andaliman fruit extract (Zanthoxylum acanthopodium DC.). The method used is a reduction in the concentration of diphenilpicrylhydrazil (DPPH). The parameter used is EC50 (the concentration of extract in reducing $50 \% \mathrm{DPPH}$ ). The DPPH test is performed by preparing $50 \mathrm{ppm}$ of $\mathrm{DPPH}$ in ethanol. Then a prepared control solution is prepared by adding $2 \mathrm{ml}$ of $96 \%$ ethanol to $1 \mathrm{ml}$ of $50 \mathrm{ppm}$ DPPH. The sample solution is prepared by making a parent solution of $100 \mathrm{ppm}$ then diluted with concentration variations of 3,5,7, and $9 \mathrm{ppm}$. The solution of each consconsection is taken $2 \mathrm{ml}$ and added $2 \mathrm{ml}$ of DPPH. All solutions are incensed for 30 minutes in a dark room at room temperature. Sample capture of DPPH is measured by UV-vis at a wavelength of $517 \mathrm{~nm}$ (Dungir, Katja and Kamu, 2012).

\subsection{Processing Techniques and Data Analysis}

Observation in terms of changes that occur in the wound and changes in the size of the wound in the area that has been treated. Data analysis uses statistical data tests including, normality test, ANOVA test to find out the effectiveness of Andaliman Fruit ethanol extract (Zanthoxylum acanthopodium DC.) and Bioplacenton ${ }^{\circledR}$ against healing the back of mice's back sores.

\section{Discussion}

\subsection{Phytochemical Screening of Andaliman Fruit Extract (Zanthoxylum acanthopodium DC.)}

Based on the results of the identification of the group of chemical compounds can be seen in the following table:

Table 1. Andaliman Fruit Phytochemical Screening (Zanthoxylum acanthopodium DC.)

\begin{tabular}{llc}
\hline \multicolumn{1}{c}{ Test } & \multicolumn{1}{c}{ Result } & Information \\
\hline \multirow{3}{*}{ Alkaloid } & Brown red deposits & $(+)$ \\
\cline { 2 - 3 } & White precipitate & $(+)$ \\
\cline { 2 - 3 } & Chocolate deposits & $(+)$ \\
\hline Flavonoid & Red color on the layer of amyl alcohol & $(+)$ \\
\hline Saponin & Permanent foam & $(+)$ \\
\hline Tanin & Blackish green color & $(+)$ \\
\hline
\end{tabular}

From the table, it can be seen that the andaliman fruit extract (Zanthoxylum acanthopodium DC.) contains chemical compounds of alkaloids, flavonoids, saponins and 
tannins. In the alkaloid test, it was found the formation of a red-brown precipitate for Dragendorff's reagent, a white precipitate resulting from the addition of Mayer's reagent, and a brown precipitate for Bouchardt's test.

\subsection{Antioxidant Testing of Andaliman Fruit Extract (Zanthoxylum acanthopodium DC).)}

Antioxidant testing is performed using the UV-Vis spectrometry method at a wavelength of $517 \mathrm{~nm}$ with 2-2-Diphenyl-1-picrylhydrazil (DPPH). The results of antioxidant testing of Andaliman Fruit extract (Zanthoxylum acanthopodium DC.) can be seen the following table:

Table 2. Percentage data on yourcanan fruit extract (Zanthoxylum acanthopodium DC.) against DPPH

\begin{tabular}{llll}
\hline Extract Concentration (ppm) & $\begin{array}{l}\text { Absorbance } \\
\text { Extract }\end{array}$ & $\begin{array}{l}\text { Absorbance } \\
\text { Extract }\end{array}$ & $\begin{array}{l}\text { Inhibisi } \\
\mathbf{( \% )}\end{array}$ \\
\hline 3 & 0.223 & 0,529 & 57.73 \\
\hline 5 & 0.219 & 0,529 & 58.48 \\
\hline 7 & 0.217 & 0,529 & 58.86 \\
\hline 9 & 0.164 & 0,529 & 68.84 \\
\hline
\end{tabular}

Based on the table above it can be seen that the absorption of DPPH by andaliman fruit extract extract (Zanthoxylum acanthopodium DC.) shows a decrease as the concentration of the extract increases. The diamond value of the extract also increased with the increase in the concentration of extracts with the largest diamond value being $68.84 \%$ at a concentration of $9 \mathrm{ppm}$. The essential oils of $\mathrm{Z}$. acanthopodium fruit have antimicrobial activity against Escherichia coli, Staphylococcus aureus, Bacillus subtalis and Streptococcus sp., but Z. acanthopodium extract is more active against $S$. aureus providing a wider resistance zone (Silalahi and Lumbantobing, 2021).

Sitanggang et al (2019), Z. acanthopodium fruit ethyl acetate extract has a bland force against E. coli that varies at a concentration of $10 \%-20 \%$ is $0.65 \mathrm{~mm}-3.15 \mathrm{~mm}$ with a weak bland category, a concentration of $30 \%-50 \%$ is $5.25 \mathrm{~mm}-6.60 \mathrm{~mm}$ medium bland category and a concentration of $60 \%-100 \%$ indicates a strong hambat category with a slave diameter of 7.20 $\mathrm{mm} 9.60 \mathrm{~mm}$. In addition to inhibiting bacterial growth, Z. acanthopodium fruit extract is also able to inhibit the growth of fungi (Sitanggang, Duniaji and Pratiwi, 2019a). The main essential noodles on the $\mathrm{Z}$ fruit. acanthopodium is $\alpha$-pinene, $\beta$ myrcene, limonene, $(\mathrm{Z})$ - $\beta$-ocimene, $(\mathrm{E})$ $\beta$ ocimenen, linalool, citronellal, $\alpha$-terpineol, $\beta$-citronellol, neral, linalool acetat, geraniol, geranial, citronellyl acetate, (Z)- $\beta$ farnesene, A sesquiterpene, cubelol, (Z)isoelemicene, A, (Z)asarone, and (E) asarone. The essential oil contained in Zanthoxylum acanthopodium has bioactivity as an anti-cancer and anti-microbial.

\subsection{Effectiveness of Andaliman fruit extract extract (Zanthoxylum acanthopodium DC.) Against the Wounds}

Based on the table below it can be seen that Bioplacenton ${ }^{\circledR}$ as a positive control experienced faster wound healing. The length of the wound on the 3rd day has experienced a reduction in the length of the wound and on the 14th day, the incision wound given bioplacenton ${ }^{\circledR}$ has had the largest percentage of cures. This is because the composition of Bioplacenton ${ }^{\circledR}$ has the active ingredients of placental extract and neomicin sulfate which is efficacious to trigger the formation of new tissue and prevent infection in the wound area 
(Aponno, Yamlean and Supriati, 2014). When viewed from the cure rate of wounds per day, on the 1st to 7 th day the wound healing rate is still linear, but on the 9th to the 14th day there is a decrease in the cure rate at a concentration of $7 \%$ compared to treatment at a concentration of $5 \%$ and far behind when compared to those given Bioplacenton ${ }^{\circledR}$.

Table 3. Changes in wound length with varying concentrations of andaliman fruit extract (Zanthoxylum acanthopodium DC.)

\begin{tabular}{|c|c|c|c|c|c|}
\hline \multirow{2}{*}{$\begin{array}{c}\text { Day To } \\
-\end{array}$} & \multicolumn{5}{|c|}{ Changes in wound length $(\mathrm{cm})$} \\
\hline & $\begin{array}{c}\text { Concentration } \\
1 \%\end{array}$ & $\begin{array}{c}\text { Concentration } \\
\mathbf{3} \%\end{array}$ & $\begin{array}{c}\text { Concentration } \\
5 \%\end{array}$ & $\begin{array}{c}\text { Concentration } \\
7 \%\end{array}$ & Bioplacenton \\
\hline 1 & 2 & 2 & 2 & 2 & 2 \\
\hline 3 & 1.8 & 1.7 & 1.7 & 1.7 & 1.7 \\
\hline 5 & 1.6 & 1.4 & 1.4 & 1.4 & 1.3 \\
\hline 7 & 1.4 & 1.1 & 1.1 & 1.2 & 0.9 \\
\hline 9 & 1.2 & 0.8 & 0.8 & 1 & 0.6 \\
\hline 11 & 1 & 0.5 & 0.5 & 0.8 & 0.4 \\
\hline 14 & 0.9 & 0.3 & 0.2 & 0.7 & 0.1 \\
\hline
\end{tabular}

When compared, the wound length at the treatment of a concentration of $5 \%$ Andaliman Fruit (Zanthoxylum acanthopodium DC.) differs only $0.1 \mathrm{~cm}$ from Bioplacenton ${ }^{\circledR}$ on the 14th day. It can be concluded that andaliman fruit extract (Zanthoxylum acanthopodium DC.) has the ability to heal wounds, although the healing speed is not as fast as Bioplacenton ${ }^{\circledR}$ when viewed from the reduction of wound length from day to day. The ability to heal these wounds may be influenced by the content of compounds present in the extract such as flavonoids, alkaloids, saponins, and tannins. In the figure below it is clear that those given Bioplacenton have the highest percentage of wound healing which is $95 \%$ with the length of the wound remaining on the 14th day is $0.1 \mathrm{~cm}$ from $2 \mathrm{~cm}$. Followed by a concentration of $5 \% \mathrm{v} / \mathrm{v}$ andaliman fruit extract extract (Zanthoxylum acanthopodium DC.), with a cure rate of $90 \%$, then with a concentration of $3 \% \mathrm{v} / \mathrm{v}$ extract of andaliman fruit extract (Zanthoxylum acanthopodium DC.) with a cure rate of $85 \%$.

\section{Wound Healing Percentage}

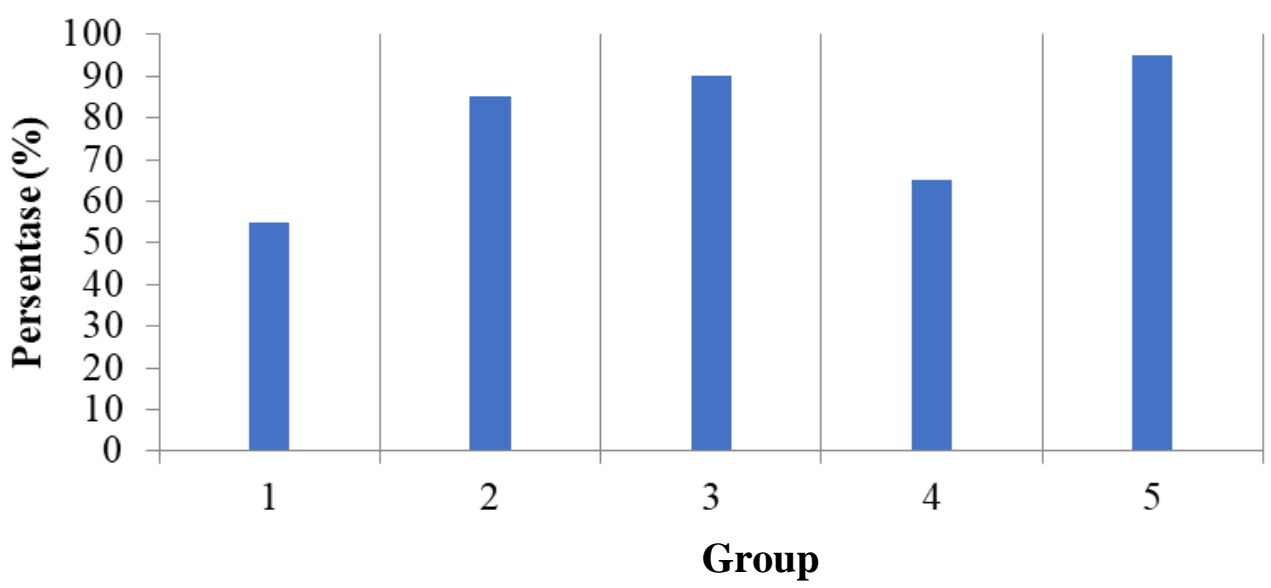

Figure 1. Percentage of Wound Cures Based on the Treatment Group of Mice 
Test the activity of andaliman fruit extract extract (Zanthoxylum acanthopodium DC.) has also been studied before by (ADELIA, 2021) The gel was $10 \%$ effective against ulcer erythema compared to the control group on the entire day of observation $(\mathrm{p}<0.05)$. On the 11 th day, erythema was no longer found in the treatment group mice while erythema in the control group mice was no longer found on the 13th day. Andaliman fruit extract gel is $10 \%$ effective against ulcer size on days 5, 10, and 14 in healing traumatic ulcers in wistar rats $(\mathrm{p}<0.05)$. Gel extract of andaliman fruit is $10 \%$ effective against erythema in healing traumatic ulcers in wistar rats $(\mathrm{p}<0.05)$.

Research Pasaribu, 2020 Showed that the antioxidant content in andaliman can also help healing by warding off free radicals (Pasaribu et al., 2020). Antioxidant content also plays a role in accelerating wound healing (Seal, 2016). The content of antioxidants in the form of alkaloids and flavonoids in andaliman plays a role in maintaining the balance of cellular redox (Rosidah et al., 2018b). Based on Rosidah's research, the alkaloid content in andaliman acts as a lipid-soluble antioxidant that serves to protect cellular membranes from free radical attacks. Andaliman also has antibacterial effects to aid wound healing and prevent secondary infections. Flavonoid, alkaloid, and tannin substances in andaliman can prevent the growth of pathogenic microorganisms such as Escherichia coli, Staphylococcus aureus, and Pseudomonas aeruginosa (Natasutedja et al., 2020). Andaliman extract can cause bacterial cells to be lysed by damaging the bacterial cell wall and increasing the permeability of the cell wall so that there is leakage of intracellular metabolites of bacteria (Sitanggang, Duniaji and Pratiwi, 2019b).

The physiological process of wound healing can be divided into four phases, namely the inflammatory phase, the destructive phase, the proliferative phase, and the maturation phase. Fase inflamasi berlangsung dari mulai terjadinya luka sampai kurang lebih hari ke 3. Hal pertama yang terjadi setelah luka adalah eraktivasinya trombosit. Pembuluh darah yang rusak pada saat terjadi luka akan menyebabkan perdarahan dan tubuh akan menghentikannya dengan vasokontriksi, pengerutan ujung pembuluh darah yang rusak, dan reaksi hemostasis (Sitanggang, Duniaji and Pratiwi, 2019a).

\subsection{Normality Test}

Results from the normality test in table 4.4 using the Kolmogorov-Smirnov method show an Absolute value of 0.090 . The kolmogorov table value for the sample number of 140 is 0.113 , then $0.90<0.113$ or the kolmogorov value calculates $<$ of the kolmogorov table value. This means the wound recovery data for the extract is normal distribution. This is also evidenced by the results of the probability test on SPSS i.e. look at the value of Asymp. Sig. (2 tailed) the value of 0.205 where $>0.05$ which means normal distribution data. For treatment on positive controls (Bioplacenton $\mathbb{R}$ ), the calculated kolmogorov value is 0.107 with $\mathrm{N}=35$. The table data with $\mathrm{N}=35$ is 0.224 , then $0.109<0.224$. Data Asymp. Sig. ( 2 tailed) shows a value of 0.800 which means data for wound healing using Bioplacenton ${ }^{\circledR}$ normal distribution, this means the entire normal distributed data.

Table 4. Kolmogorov-Smirnov Normality Test Results

\begin{tabular}{|c|c|c|c|}
\hline & & $\begin{array}{l}\text { Wound Healing } \\
\text { (Extract) }\end{array}$ & $\begin{array}{l}\text { Wound Healing } \\
\text { (Bioplacenton }{ }^{\circledR} \text { ) }\end{array}$ \\
\hline $\mathrm{N}$ & & 140 & 35 \\
\hline \multirow{2}{*}{ Normal Parameters ${ }^{\mathrm{a}, \mathrm{b}}$} & Mean & 1.0970 & 1.0282 \\
\hline & Std. Deviation & .56998 & .63317 \\
\hline Extreme & Absolute & .090 & .109 \\
\hline
\end{tabular}




\begin{tabular}{llrr} 
Differences & Positive & .090 & .098 \\
& Negative & -.089 & -.107 \\
Kolmogorov-Smirnov Z & & 1.062 & .642 \\
Asymp. Sig. (2-tailed) &. $\mathbf{2 0 6}$ & $\mathbf{. 8 0 4}$ \\
\hline a. Test distribution is Normal. & & \\
b. Calculated from data. & &
\end{tabular}

\subsection{Effectiveness of Andaliman Fruit Extract (Zanthoxylum acanthopodium DC.) Against the Healing of Wounds}

The effectiveness of the entire concentration of andaliman fruit extract (Zanthoxylum acanthopodium DC.) against wound healing can be seen with analysis of variance (ANOVA) or variance analysis (ANAVA). The ANOVA test is a significance test to see the difference in the administration of andaliman fruit extract (Zanthoxylum acanthopodium DC.) to wound healing. The results of the test can be seen in the following table:

Table 5. Results of The Effect Test of Extracting Andaliman Fruit Extract (Zanthoxylum acanthopodium DC.) On the Healing of My Wounds

\begin{tabular}{llrrrrrr}
\hline \multicolumn{7}{c}{ ANOVA } \\
\hline & \multicolumn{2}{c}{$\begin{array}{c}\text { Sum of } \\
\text { Squares }\end{array}$} & df & $\begin{array}{c}\text { Mean } \\
\text { Square }\end{array}$ & F & \multicolumn{2}{c}{ Sig. } \\
\hline Andaliman Fruit & & Between Groups & 6.843 & 3 & 2.280 & 8.091 & .000 \\
\cline { 2 - 8 } Extract & Within Groups & 38.316 & 136 & .280 & & \\
\cline { 2 - 8 } & Total & 45.159 & 139 & & & \\
\hline
\end{tabular}

The table above shows the Fhitung value of 8,091 . To find the value in table value $F$ for $\mathrm{df}=3 / 136$ with probability $(\alpha)$ of 0.05 obtained ftabel value of 2.67 . So that the value of Fhitung $>$ Ftabel which means that overall there is a real influence on the administration of Andaliman Fruit extract (Zanthoxylum acanthopodium DC.) on the healing of wounds. To confirm this hypothesis test, it can be seen in the sig value. Calculate 0.000 while sig value $(\alpha)$ is 0.05 which means sig value. Count $\operatorname{sig}<(\alpha)$. This means that there is a real influence of the administration of andaliman fruit extract (Zanthoxylum acanthopodium DC.) on the healing of scratch wounds in mice.

\subsection{Bioplacenton Effectiveness ${ }^{\circledR}$ On Wound Healing}

The effect or effectiveness of Bioplacenton ${ }^{\circledR}$ on wound healing can be reviewed with the Anova test. The results of the test can be seen in the following table:

Table 6. Results of Bioplacenton ${ }^{\circledR}$ (positive control) Effect Test on Wound Length ANOVA

\begin{tabular}{lccccc}
\hline & $\begin{array}{c}\text { Sum of } \\
\text { Squares }\end{array}$ & Df & Mean Square & F & Sig. \\
\hline Between Groups & 11.927 & 6 & 1.982 & 32.662 & .000 \\
\hline Within Groups & 1.704 & 28 & .060 & & \\
\hline Total & 13.631 & 34 & & \\
\hline
\end{tabular}

Based on the table above it can be seen that the value of Fhitung is 32.662 while the value of Ftabel is 2.45 which means Fhitung $>$ Ftabel. When viewed the sigifiance value, the signinifikan value of the count is 0.000 which is smaller than the alpha value of 0.05 or $p<$ 0.05. From this data it can be concluded that there is a real influence in the provision of 
Bioplacenton ${ }^{\circledR}$ on the healing of my wounds (Yulianto et al., 2020). The wound healing process becomes important because the skin is a single organ that is exposed to the outside world. The skin has specific functions for the body, namely protective, sensory, thermoegulatoric, metabolic, and sexual signals. When the skin loses its continuity, those functions cannot run as they should. Therefore, the wound healing process requires proper management and treatment so that the wound area does not become infected and eventually cause chronic wounds. Bioplacenton ${ }^{\circledR}$ is one of the gels that can be used for wound healing. This gel contains $10 \%$ placental extract and $0.5 \%$ neomycin sulfate. Placenta extract works to trigger the formation of new tissue and neomycin sulfate prevents infection in the wound area. Placenta extract works to help the wound healing process and trigger the formation of new tissue, while neomycin sulfate serves to prevent or overcome bacterial infections in the wound area (Aponno, Yamlean and Supriati, 2014).

Wounds can be classified based on the nature, anatomical structure, healing process, length of healing, as well as the depth and extent of the wound. By its nature, wounds are divided into abrasion wounds, contusions, incisions, lacerations, penetration, puncture, sepsis, and others. Based on its anatomical structure, wounds are classified into superficial wounds that include superficial parts of the skin i.e. epidermis (sometimes able to get to the upper layer of the dermis), partial thickness wounds involving the epidermis and dermis layers, as well as full thickness wounds involving all layers of skin from the epidermis, dermis, fat layer, fascia, even to the bones. Based on the healing process, wounds can be classified into three, namely primary wound healing, secondary wound healing and Delayed Primary Healing. In the primary healing process the edges of the wound can re-fuse, the surface is clean, and no tissue is lost (Kartika et al., 2015).

Wound healing is a natural repair process against tissue injury by involving inflammatory mediators, blood cells, extracellular matrix, and cell parenchyma. The process consists of three phases; hemostasis and inflammation, proliferation, as well as maturation and remodeling. Any type of trauma that causes vascular injury will initiate a cellular response to begin the hemostasis phase. This phase lasts from the occurrence of the injury until approximately the fifth day. Its main contributions are vaso constriction, platelet aggregation and fibrin deposition so that blood clot formations are formed. Meanwhile, there is an inflammatory reaction in the form of eritem, edem, pain, and heat with the aim of bringing inflammatory cells to the wound area (Revina et al., 2018). Wound healing is a complex biological process that results in the recovery of integrity tissues. Physiologically, the wound healing process can be divided into four glutting values of hemostasis, inflammation, proliferation and tissue rermulelling. Many factors are known to slow wound healing, namely malnutrition, hypoxia. Immunosuppression, chronic diseases and post-surgical conditions. It is very important for the surgeon to understand the physiological processes involved in wound healing to maximize the patient's morbidity from the delayed wound healing process (Suryadi, 2013).

\section{Conclusion}

Based on the results of research and data analysis, it can be concluded that andaliman fruit extract has several bioactive compounds such as alkaloids, flavonoids, saponins, and tannins that play a role in wound healing. The optimum concentration of Saleb Andaliman fruit essential oil that can heal wounds in white rats is $5 \%$. The highest percentage of cures on

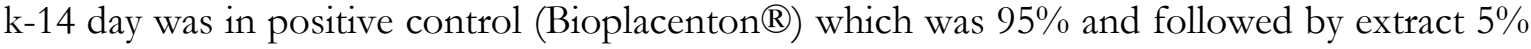
$\mathrm{v} / \mathrm{v}$ with a cure percentage of $90 \%$. Essential oil of andaliman fruit extract has the ability to approach Bioplacenton ${ }^{\circledR}$ in healing wounds in mice. 


\section{References}

Adelia, D. P. (2021) 'Efektivitas Gel Ekstrak Buah Andaliman (Zanthoxylum Acanthopodium Dc.) $10 \%$ terhadap Penyembuhan Ulkus Traumatikus Dina Priscila Adelia Fakultas Kedokteran Gigi Universitas Sumatera Utara', Fakultas Kedokteran Gigi Universitas Sumatera Utara Medan 2021.

Adolf J. N. Parhusip (2006) Kajian Mekanisme Antibakteri Ekstrak Andaliman (Zanthoxylum acanthopodium) terhadap Bakteri Patogen Pangan. Sekolah Pascasarjana Institut Pertanian Bogor. doi: 10.1017/CBO9781107415324.004.

Afandi, D. (2017) Tata Laksana dan Teknik Pembuatan Visum et Repertum, University of Riau Press.

Aponno, J. V, Yamlean, P. V. Y. and Supriati, H. S. (2014) 'Uji Efektivitas Sediaan Gel Ekstrak Etanol Daun Jambu Biji (Psidium Guajava Linn) Terhadap Penyembuhan Luka Yang Terinfeksi Bakteri Staphylococcus Aureus Pada Kelinci (Orytolagus Cuniculus)', Pharmacon, 3(3), pp. 279-286. doi: 10.35799/pha.3.2014.5400.

Asbur, Y., K. (2018) 'Pemanfaatan Andaliman (Zanthoxylum acanthopodium DC) sebagai Tanaman Penghasil Minyak Atsiri', Jurnal Kultivasi, 17(1), pp. 537-543. doi: https://doi.org/10.24198/kltv.v17i1.

Dungir, S. G., Katja, D. G. and Kamu, V. S. (2012) 'Aktivitas Antioksidan Ekstrak Fenolik dari Kulit Buah Manggis (Garcinia mangostana L.)', Jurnal MIPA, 1(1), p. 11. doi: 10.35799/jm.1.1.2012.424.

Hardhani, P. R., Lastianny, S. P. and Herawati, D. (2014) 'Pengaruh Penambahan Platelet Rich Plasma Pada Bovine Porous Bone Mineral Terhadap Penyembuhan Jaringan PHardhani, P. R., Lastianny, S. P., \& Herawati, D. (2014). Pengaruh Penambahan Platelet Rich Plasma Pada Bovine Porous Bone Mineral Terhadap Penyembuhan', Journal Kedokteran Gigi, 5(4), pp. 342-48. Available at: https://journal.ugm.ac.id/jkg/article/download/29330/17505.

Hernawati, S. (2015) 'Ekstrak Buah Delima sebagai Alternatif Terapi Recurrent Apthous Stomatitis (RAS)', Stomatognatic, 12(1), pp. 20-25.

Kartika, R. W. et al. (2015) 'Perawatan Luka Kronis dengan Modern Dressing', Perawatan Luka Kronis Dengan Modern Dressing, 42(7), pp. 546-550.

Kosasih, E. et al. (2019) 'Hepatoprotective Effect of Citrus Sinensis Peel Extract Against Isoniazid and Rifampicin-induced Liver Injury in Wistar Rats', Majalah Obat Tradisional, 24(3), pp. 197-203. doi: 10.22146/mot.45762.

Muzafri, A. (2019) 'Uji Aktivitas ANtimikroba Ekstrak Andaliman (Zanthoxylum acanthopodium DC.) pada Staphylococcus aureus', Jurnal Sungkai, 7(1), pp. 122-126. doi: 10.1017/CBO9781107415324.004.

Natasutedja, A. O. et al. (2020) 'Botanical Aspects, Phytochemicals and Health Benefits of Andaliman (Zanthoxylum acanthopodium)', Indonesian Journal of Life Sciences, 02(01), pp. 8-15.

Novyana, R. M. and Susanti (2016) 'Lidah Buaya (Aloe vera) untuk Penyembuhan Luka', Jurnal Kedokteran Universitas Lampung, 5, pp. 149-153.

Pasaribu, K. M. et al. (2020) 'Fabrication and in-vivo study of micro-colloidal Zanthoxylum acanthopodium-loaded bacterial cellulose as a burn wound dressing', Polymers, 12(7). doi: $10.3390 /$ polym12071436.

Purba, S. T. and Sinaga, D. P. (2017) 'Evaluasi Potensi Ekstrak Tumbuhan Andaliman (Zanthoxylum acanthopodium) sebagai Potensi Imunostimulan pada Tikus (Rattus norvegicus L.)', in Prosiding Seminar Nasional III Biologi dan Pembelajarannya. Universitas Negeri Medan. 
Revina, M. et al. (2018) 'Efektivitas Ekstrak Daun Mangkokan Terhadap Penyembuhan Luka Bakar Pada Tikus Efektivitas Ekstrak Daun Mangkokan Terhadap Penyembuhan Luka Bakar Pada Tikus Program Studi Pendidikan Dokter, Universitas Prima Indonesia, Medan Fakultas Kedokteran, Univers', Scientia Journal, 7(2), pp. 166-172.

RISKESDAS (2013) 'Riskesdas', Badan Penelitian dan Pengembangan Kesehatan Kementerian Kesehatan RI, 7(5), pp. 803-809. doi: 10.1517/13543784.7.5.803.

Rosidah et al. (2018a) 'Antioxidant activity of alkaloid fractions of zanthoxylum acanthopodium dc. Fruits with 1,1-diphenyl-2-picrylhydrazyl assay', Asian Journal of Pharmaceutical and Clinical Research, 11(13), p. 33. doi: 10.22159/ajpcr.2018.v11s1.26560.

Rosidah et al. (2018b) 'Antioxidant activity of alkaloid fractions of zanthoxylum acanthopodium dc. Fruits with 1,1-diphenyl-2-picrylhydrazyl assay', Asian Journal of Pharmaceutical and Clinical Research, 11(Special Issue 1), pp. 33-34. doi: 10.22159/ajpcr.2018.v11s1.26560.

Salmerón-Manzano, E., Garrido-Cardenas, J. A. and Manzano-Agugliaro, F. (2020) 'Worldwide research trends on medicinal plants', International Journal of Environmental Research and Public Health, 17(10). doi: 10.3390/ijerph17103376.

Saragih, D. E. and Arsita, E. V. (2019) 'The phytochemical content of Zanthoxylum acanthopodium and its potential as a medicinal plant in the regions of Toba Samosir and North Tapanuli, North Sumatra', Prosiding Seminar Nasional Masyarakat Biodiversitas Indonesia, 5(1), pp. 71-76. doi: 10.13057/psnmbi/m050114.

Seal, T. (2016) 'HPLC determination of phenolic acids, flavonoids and ascorbic acid in four different solvent extracts of zanthoxylum acanthopodium, a wild edible plant of meghalaya state of india', International Journal of Pharmacy and Pharmaceutical Sciences, 8(3), pp. 103-109.

Silalahi, M. and Lumbantobing, K. (2021) 'Kandungan Minyak Atsiri Andaliman (Zanthoxylum acanthopodium DC) dan Bioaktivitasnya', jurnal Pro-Life, 8 No.1, p. 31.

Sitanggang, F. M. C., Duniaji, A. S. and Pratiwi, I. D. P. K. (2019a) 'Daya Hambat Ekstrak Buah Andaliman (Zanthoxylum acanthopodium DC) dalam Etil Asetat terhadap Pertumbuhan Escherichia coli', Jurnal Ilmu dan Teknologi Pangan, 8(3), pp. 257-266.

Sitanggang, F. M. C., Duniaji, A. S. and Pratiwi, I. D. P. K. (2019b) 'Daya Hambat Ekstrak Buah Andaliman (Zanthoxylum Acanthopodium Dc) dalam Etil Asetat terhadap Pertumbuhan Escherichia coli', Jurnal Ilmu dan Teknologi Pangan (ITEPA), 8(3), p. 257. doi: 10.24843/itepa.2019.v08.i03.p04.

Sriwichai, T. et al. (2019) 'Zanthoxylum spp. : A new potential sources of essential oil for the perfumery and pharmaceutical industries in Thailand', Medicinal Plants, 11(1), pp. 2645. doi: 10.5958/0975-6892.2019.00009.1.

Suarni, E. and Prameswarie, T. (2015) 'Perbandingan Pemberian Gel Lidah Buaya (Aloe vera L.) dan Povidone Iodine terhadap Waktu Penyembuhan Luka Iris (Vulnus scissum) pada Mencit (Mus musculus) Galur Wistar', Syifa' MEDIKA: Jurnal Kedokteran dan Kesehatan, 5(2), p. 82. doi: 10.32502/sm.v5i2.1397.

Suryadi, I. A. (2013) 'Wound Healing Process and Wound Care', e-Jurnal Medika Udayana, 2(2), pp. 254-272.

Widowati, W. et al. (2016) 'Antioxidant and Anti Aging Assays of Oryza sativa Extracts, Vanillin and Coumaric Acid', Journal of Natural Remedies, 16(3), pp. 88-99. doi: $10.18311 /$ jnr/2016/7220.

Widowati, W. et al. (2017) 'Antioxidant and antiaging assays of Hibiscus sabdariffa extract and its compounds', Natural Product Sciences, 23(3), pp. 192-200. doi: 10.20307/nps.2017.23.3.192. 
Widowati, W. et al. (2018) 'Antioxidant and antiaging activities of Jasminum sambac extract, and its compounds', Journal of Reports in Pharmaceutical Sciences, 7(3), pp. 270-285.

Wijaya, C. H. et al. (2019) 'A review of the bioactivity and flavor properties of the exotic spice "andaliman” (Zanthoxylum acanthopodium DC.)', Food Reviews International, 35(1), pp. 1-19. doi: 10.1080/87559129.2018.1438470.

Winarti, W., Simanjuntak, P. and Syahidin, M. F. (2018) 'Identifikasi Senyawa Kimia Aktif Antioksidan Dari Ekstrak Etil Asetat Buah Andaliman (Zanthoxylum acanthopodium DC)', in Talenta Conference Series: Tropical Medicine (TM). Medan: Talenta Publisher, pp. 162-166. doi: 10.32734/tm.v1i3.283.

Wissen, S. et al. (2020) 'Perbedaan Waktu Penutupan Luka Insisi yang Diaplikasikan Solutio Povidone Iodine $10 \%$ dengan Unguentum Kloramfenikol $2 \%$ pada Mencit Swiss Webster', 2(6), pp. 138-144. Available at: https://journal.maranatha.edu/index.php/jmh/article/view/2036.

Worotikan, R. V., Tuju, E. A. and Kawuwung, F. (2017) 'Analisa Efektivitas Antidiabetes Ekstrak Etanol Buah Andaliman (Zanthoxylum acanthopodium DC) pada Histopatologi Ginjal Tikus Putih (Rattus norvergicus) yang Diinduksi Alloksan', Jurnal Sains Matematika \& Edukasi, 5(1), pp. 29--37.

Yanti et al. (2011) 'Lemon Pepper Fruit Extract (Zanthoxylum acanthopodium DC.) Suppresses the Expression of Inflammatory Mediators in Lipopolysaccharide-Induced Macrophages In Vitro', American Journal of Biochemistry and Biotechnology, 7(4), pp. 190-195. doi: 10.3844/ajbbsp.2011.190.195.

Yulianto, R. et al. (2020) 'Efek Ekstrak Metanol Daun Ketapang (Terminalia catappa L.) Terhadap Kepadatan Kolagen dalam Penyembuhan Luka Bakar Derajat II pada Tikus Putih (Rattus norvegicus)', Jurnal Medik Veteriner, 3(1), p. 82. doi: 10.20473/jmv.vol3.iss1.2020.82-88. 